LEGAL AND POLITICAL SCIENCE

\title{
SOME FEATURES OF THE HYBRID MODEL OF CORPORATE GOVERNANCE
}

\author{
K. Kokrashvili, Doctor of Law, Professor of Georgian Technical University, Tbilisi, Georgia \\ DOI: https://doi.org/10.31435/rsglobal_conf/25122020/7305
}

\begin{abstract}
In the present article "Some features of the hybrid model of corporate governance", based on comparative analysis, the monistic, dual and hybrid models of corporate governance and their features are discussed. Particular attention is paid to the hybrid model of corporate governance as a relatively innovative model.

The purpose of this study is to review recent changes in corporate governance practices, especially in Georgia in terms of institutional continuity and change. This is due to the fact that successful economic development and institutional reform became increasingly central to the economy, and interest in institutional change increased significantly.

Georgian legislation introduced a hybrid model in corporate governance back in 2008, but these changes have led to confusion over the functions of governing bodies, which has had a negative impact in practice. The article presents less Georgian legislation in this regard and perspectives for its improvement.

Keywords: Corporate governance models. A hybrid model of corporate governance. Corporate governance and gaps in Georgian entrepreneurial legislation.
\end{abstract}

Introduction. Corporate governance is the system by which companies are directed and controlled. Corporate governance is the structure of rules, practices, and processes used to direct and manage a company.

The corporate governance system is an organizational model that is designed, on the one hand, to regulate the relationship between the managers of companies and their owners, on the other, to coordinate the goals of various stakeholders, ensuring the efficient functioning of companies.

Selecting the best management model is essential for companies to work more efficiently, improve access to capital, avoid risk, and protect stakeholders. It also makes companies more accountable and transparent, arousing investor interest. Corporate governance describes corporate values and norms. It ensures that the board of directors is accountable for the pursuit of corporate objectives and that the corporation itself conforms to the law and regulations. Companies need to permanently improve corporate governance. In the absence of effective governance, companies face different kinds of difficulties, there is no greater risk for the company than poor governance.

The Harvard Law Forum writes: The UK Corporate Governance Code exists because companies do not exist in isolation. Successful and sustainable businesses underpin our economy and society by providing employment and creating prosperity. To succeed in the long-term, directors and the companies they lead need to build and maintain successful relationships with a wide range of stakeholders. These relationships will be successful and enduring if they are based on respect, trust and mutual benefit. Accordingly, a company's culture should promote integrity and openness, value diversity and be responsive to the views of shareholders and wider stakeholders. ${ }^{1}$

Research Results. In order to increase the role of corporate governance in attracting investment and the effectiveness of companies, the Organization for Economic Co-operation and Development (OECD) Corporate Governance Principles were published in $1999^{2}$, which set out the standards and guidelines that underpin the development and improvement of corporate governance systems. These principles have become the basis for corporate governance in both OECD and OECD non-member countries. As a result, the OECD Principles have been adopted as the Financial Stability Forum, one of the standards for the stability of financial systems.

OECD definition of corporate governance: The corporate governance structure specifies the distribution of rights and responsibilities among the different participants in the organization - such as the board, managers, shareholders and other stakeholders - and lays down the rules and procedures for decision-making. The purpose of corporate governance is to facilitate effective, entrepreneurial and prudent management that promotes the long-term success of the Company and generates value for

\footnotetext{
${ }^{1}$ https://corpgov.law.harvard.edu/2018/07/17/the-uk-corporate-governance-code/

${ }^{2}$ Editorial changes came in 2004
} 
shareholders and contributes to all our stakeholders whether customers, suppliers, employees, the government or wider society. ${ }^{1}$

OECD principles of corporate governance are not legally binding. Their goal is to define goals for achieving effective corporate governance and propose means of achieving them. The implementation of the principles will serve both the interests of the corporations themselves and the interests of the state, since investors are interested in implementing more acceptable corporate governance practices.

As the home of good governance, ICSA believes that good governance is important as it provides the infrastructure to improve the quality of the decisions made by those who manage businesses. Good quality, ethical decision-making builds sustainable businesses and enables them to create long-term value more effectively. ${ }^{2}$

The best corporate governance, as a rule, should help to attract more foreign investments into transition economies to help accelerate growth and enhance their balance of payments positions; and reduce gradually the extent of state involvement in the business sector.

The best corporate governance principles are established in practice, namely:

- An ethical approach towards society must be a key organizational paradigm;

- Objectives should be balanced and respect the goals of all interested parties;

- The roles of key players such as the board, the management or staff/stakeholders must be clarified;

- A decision-making process must be in place - reflecting the first three principles and giving due weight to all stakeholders;

- Equal concern must be given for all stakeholders - albeit some have greater weight than others;

- Accountability and transparency is necessary - to all stakeholders. ${ }^{3}$

As a rule, Corporate governance covers both the social and institutional aspects of a business. Properly thought out and effective corporate governance promotes a culture of company integrity, which in turn leads to positive performance and sustainable business development. This increases the accountability of all individuals and teams in the company, which works to prevent mistakes.

It is determined as a result of research, that good corporate governance can increase access companies to external financing, attraction of new investments, higher rates of economic growth and creation of new jobs; good corporate governance can lower standing capital and increase the standing of companies, parts of investments that are attractive, which lead to a further economic growth and increase of employment; effective corporate governance reduces risk financial crisis that could lead to devastating economic and social consequences and finally, effective corporate governance leads to improving relationships with all interested parties (stakeholders) and, accordingly, improve labor relations, as well as creating conditions for work over social issues, in particular, protection issues environment.

Historically, the corporate governance system and legal regulation are different in continental European countries and in common law countries. Europe has chosen the path of legislative regulation to put an end to the misuse of corporate law norms. In contrast to German law, in the United States, the competence of governing bodies was less defined by law, especially by the development of imperative norms.

Several models of corporate governance are known in the world today, for example - AngloAmerican Model; German Model; Social Control Model; Japanese Model etc. The existence of corporate governance systems is the result of different economic and legal bases, which depend on many indicators of business development, as well as the specific specifics of entrepreneurial legislation.

Under the Anglo-American Model of corporate governance, the shareholder rights are recognized and given importance. They have the right to elect all the members of the Board and the Board directs the management of the company. ${ }^{4}$ It is also called a one - tier, or monistic management system. The one-tier system is distinguished as two governing bodies provided by law. It is the General Meeting of Shareholders, which is the main governing body of the company and its Board of Directors.

The Board of Directors consists of two, functionally distinct members:

- The members of the Board who represent the company in its day-to-day operations (the socalled "insider", CEOs) and

\footnotetext{
${ }^{1}$ https://www.icaew.com/technical/corporate-governance/principles/principles-articles/does-corporate-governance-matter ${ }^{2} \mathrm{https}$ ://www.icsa.org.uk/about-us/policy/what-is-corporate-governance

${ }^{3}$ Applied Corporate Governance, 2013, Best Corporate Governance Practice, Applied Corporate Governance, http://www.applied-corporate-governance.com/best-corporate-governance-practice.html, accessed 02.12.2015

${ }^{4} \mathrm{https} / /$ www.papertyari.com/general-awareness/management/corporate-governance-models/
} 
- The members of the Board with supervisory and controlling powers, whose activities are representative Control over the activities of directors (so-called "non-insider", non-executive directors).

In order to avoid various conflicts of interest within the company, the controlling members of the board are independent directors who have no financial and / or other legal connection with the company and / or any of its subsidiaries.

As for the German model, it is known as two-tier board, or dual model. This model of corporate governance is used in European companies. Two boards are implied:

$\checkmark$ Supervisory Board - The shareholders and also Employees elect the members of Supervisory Board, which are generally one-third or half of the Board and

$\checkmark$ Management Board: The Supervisory Board appoints and also Controlled the Management Board.

The Supervisory Board has the right to dismiss the Management Board and re-constitute the same. The dualistic model separates the management and control functions of the company through completely independent governing bodies. Hierarchically, the Board of Directors is accountable to the Supervisory Board and the General Meeting of Shareholders. Unlike the monistic model, in the dualistic model, none of the members of the board of directors is a controlling entity. This function has been delegated to the Supervisory Board. The Board of Directors is responsible for the operational activities and it will represent the company in external relations.

The American and German models of corporate governance are two opposite systems, between which there are many options with the predominant dominance of one system or another and reflecting the national characteristics of a particular country.

The main differences between the considered models of corporate governance are as follows:

$\checkmark$ In the American model, the interests of shareholders are, for the most part, the interests of small private investors isolated from each other, who, due to their disunity, are highly dependent on the management of corporations;

$\checkmark$ In the German model, shareholders are a collection of fairly large holders of blocks of shares, and therefore they can unite among themselves to pursue their common interests and, on this basis, have firm control over the management of a joint-stock company.

In addition to monistic and dualistic management models, there is also a hybrid (mixed) model, this model of corporate governance is common in France, Belgium, Japan, Poland, Georgia etc.

There can be no single, universal model of corporate governance in the world. In modern conditions, different models of corporate governance are merged, which is due to the fact that neither model has an advantage over the other. possible combination of different models of corporate governance, borrowing of separate elements of that or other models and their development. In the context of globalization of financial and commodity markets, increasing convergence of legal and institutional norms, open exchange of ideas and information, and attention to foreign experience, the process of convergence of corporate governance models is underway. ${ }^{1}$ It is therefore not surprising why more and more companies in the country are interested in the corporate governance model. It should be noted, however, that more caution is required when selecting this model, especially for countries inexperienced in doing business. This is well illustrated by the example of Georgia, which has moved to a hybrid model of corporate governance since 2008. In connection with the change of the corporate model, incompatible norms appeared in the Georgian entrepreneurial legislation, which increased the practical problems (some of them will be discussed below).

In general, under the hybrid (mixed) model, companies have the opportunity to form a board of directors with executive and non-executive functions typical of a one-tier system. At the same time, they should form a supervisory board and define in the founding document of the company the possibility for any member of the board of directors to be a member of the supervisory board at the same time. For example, French law gives all limited companies the choice between: A unitary formula with a Board of Directors; A two-tier structure with a Management Board and a Supervisory Board based on a distinction between management functions and the supervision of this management (similar to the German model). Moreover, companies with a Board of Directors have a choice between

\footnotetext{
${ }^{1}$ Radygii A.D., Eshpov R.M. Unification of corporate legislation: global trends, EU legislation and Russian prospects. M., 2002. S. 34; Dementyeva A.G. Models of corporate governance: experience of foreign countries and Russia // Legal Management. XXI Century. 2008. No. 3. P. 80; Models of corporate governance in Russia: development and influence on the policy of industrial enterprises // Enterprises of Russia. Corporate governance and market transactions: collection of articles. articles. M., 2002. S. 129-224. Ch. 2.
} 
separating and combining the offices of Chairman and Chief Executive Officer. Most companies in France (almost 80\%) have a single level or unitary board. In general, under the mixed model, companies have the opportunity to form a board of directors with executive and non-executive functions typical of a one-tier system. At the same time, they should form a supervisory board and define in the founding document of the company the possibility for any member of the board of directors to be a member of the supervisory board at the same time. Under French law, the Chairman of the Board of Directors has an essentially administrative and leadership role. ${ }^{1}$

The Belgian corporate governance rules evolved over the past few years from soft law (the Lippens Code and the 2009 Code) to hard law (BCCA), and the process is ongoing. On 23 March 2019, a new Belgian Code of Companies and Associations (BCCA) was adopted, resulting in a fundamental reform of Belgian corporate law (Updated Corporate Governance Code to take effect in Belgium from 1 January 2020). There are three models of corporate governance in Belgium today:

- One-tier, or monistic management model (a board of directors consisting of at least three directors);

- A two-tier model, consisting of a supervisory board (raad van toezicht / conseil de surveillance) and a board of directors (directieraad / directieraad);

- Sole director having the most extensive powers to manage the company alone, excluding actions which are reserved by law to the shareholders' meeting. ${ }^{2}$

The choice of governance formula is based on the fact that: 1 . The board of directors must be able to decide in the best interests of the company according to its specific characteristics, particularly its business sector, shareholder composition and even the characteristics of its executive management team.

Japanese systems of corporate governance neither fully converge to, nor completely diverge from, the Anglo-American model. Rather, Sony - the pioneer of corporate governance reforms - and its followers selectively adopted features from this model, decoupled them from the original context, and tailored them to fit to their own situations to generate governance innovation. However, we find that the spread of innovation across firms and institutional levels is far from linear and straightforward, and that other well-regarded firms raised strong opposition to the institutionalization of corporate governance reforms. Eventually, the Ministry of Justice revised the Commercial Code to legitimize different systems, which led to the emergence of diverse corporate governance practices.

As for Poland - Poland along with other members of the transition economies of Central and Eastern Europe (CEE) have adopted a hybrid corporate governance model, which draws inspirations from both the insider-oriented system as exemplified in Germany and the outsider-oriented system as exemplified in the UK.

Poland's hybrid corporate governance system to align with the country's socio-economic-legal framework and also takes into account the common positive features found in both the insider-oriented system and the outsider-oriented system; and in particular the emphasis on transparency and accountability, proper corporate asset management, and investors' protection safeguards. ${ }^{3}$

One of the important features of the hybrid model is the existence of several prerequisites provided by law, during which the company was required to establish a supervisory board. In other cases, it depends on the will of the shareholders whether a supervisory board will be established, however, in any case, the system under consideration determines the functions of the board of directors responsible for managing and representing the company.

A little about the corporate governance model in Georgia. It is noteworthy that the corporate governance model in Georgia until 2008 was based on the German model. In 2008, the Law on Entrepreneurs was amended, as a result of which Georgia switched from the German model of corporate governance to a hybrid model.

However, the changes had serious deficiencies, in terms of management (Which created problems in practice). For example, the functions of the board of directors and the supervisory board were confused; It was allowed to transfer the functions of the director to the supervisory board; It was possible for the director to be a member of the supervisory board. The logical question is - if the director of the company is also a member of the supervisory board, will this lead to a reduction of control over the directorate by the supervisory board? Of course, the director, who is also a member of

\footnotetext{
${ }^{1}$ See details: https://frenchcorporategovernance.wordpress.com/the-french-model/

${ }^{2}$ See details: https://uk.practicallaw.thomsonreuters.com/w-026-

0629 ?originationContext $=$ document\& transitionType $=$ DocumentItem\&contextData $=($ sc. Default $) \&$ firstPage $=$ true

${ }^{3}$ Peter Yeoh. Corporate governance models: Is there a right one for transition economies in Central and Eastern

Europe? ISSN: 0309-0558. Publication date: 22 May 2007
} 
the supervisory board, can not control himself effectively and efficiently, and the rule of law that directors can not form a majority on the supervisory board does not provide adequate guarantees. The board of directors with the participation of the directors is more like the American board (the board of directors) than the German supervisory board (Aufsichtsrat).

It should also be noted that, the law does not provide for the existence of independent directors (so-called "Non-management Directors"). In situations where the Supervisory Board is no longer a mandatory body, it is important to have control over the activities of the Directorate.

Naturally, for investors who are going to invest money, great importance is attached to how decisions are made and whether control over the director's decisions is exercised. The control over the implementation of the decision is, of course, exercised by the directorate itself. The investor is interested in how this body makes decisions and whether there is effective control over the decisionmaking process. ${ }^{1}$ The presence of independent directors on the board is an important signal for investors, as this fact shows that the management is always ready to be "checked" by independent professionals, Also, directors are more protected from lawsuits filed against them by shareholders. As you can see, according to the current version of the entrepreneurs, the rights and functions of the directorate have been increased and the control has been weakened as much as possible. The current situation is unfortunately unfavorable for potential investors.

Conclusions. Practice analysis shows that attempts at hybrid governance have improved efficiency, but questions and concerns remain about the transparency and accountability of such blended corporations. However, it is noteworthy that the concept of hybridisation is fairly new, and involves combining different approaches to corporate governance, eg it embraces combining elements of the board management and monitoring models.

Given the material presented in the article, it is clear how important the best model of corporate governance is and its ongoing development process. This is especially important for less experienced countries like Georgia. For the purpose of integration of Georgian corporate law into European corporate law, an Association Agreement was signed between the EU and Georgia in June 2014 and entered into force on 1 July 2016. According to the agreement, Georgian corporate law must comply with EU corporate law directives. In this format, a new law "On Entrepreneurs" will enter into force in Georgia on January 1, 2021, which once again declared a hybrid model of corporate governance, at the same time, the main thing is to correct the less of the law, concerned with confusing the functions of governing bodies.

According to the draft law, „A joint stock company may have a dualistic or monistic management system. The management system is dualistic, where in the joint stock company, in addition to the meeting of partners and the governing body, there is a supervisory board, and the management system is monetary, where there is no supervisory board in the joint stock company. Accordingly, when choosing a monistic management system, the bodies of a joint stock company are the meeting of partners and the governing body, and when choosing a dual management system - the meeting of partners, the supervisory board and the governing body” (Article, 5); also „A joint stock company may have a dualistic or monistic management system. It is a dual management system where the joint stock company, in addition to the meeting of partners and the governing body, has a supervisory board. There is a monistic management system where the joint stock company does not have a supervisory board. The decision on the choice of management system is made at the establishment of the joint stock company and is mentioned in the charter of the joint stock company. The decision to choose a management system can be changed if the change is supported by at least $3 / 4$ of the votes cast in the meeting of the partners" (Article, 184).

Georgia aspires to become a country based on European values and to integrate politically and economically with Europe. This requires correct solution of socio-economic tasks. We think that these legislative changes will regulate the management issues in Georgian corporate law, eventually a hybrid model of corporate governance will be formed and hopefully the existing problems will be eliminated. Our ultimate goal is to establish ourselves in the European legal area and become a full member of the EU corporate law family. The most important thing is the reform of corporate law in Georgia is being implemented to improve corporate governance in the region by learning from past failures and achievements - not just by copying best practices, as has been the case in the past.

\footnotetext{
${ }^{1}$ Tsertsvadze L., Duties of the Directorate in Merging Companies and Selling a Controlling Stake, World of
} Lawyers, Tbilisi, 2016. 
Presented article does not argue that the hybrid model can necessarily result in a stable system. The change in corporate governance is not supposed to be finished, and new developments take place even today. We believe that fundamental questions about the effectiveness of new models of corporate governance in the future remain, which in turn is stimulating new research on issues and it will definitely help relatively inexperienced countries like Georgia to improve their corporate governance reform.

\section{REFERENCES}

1. Applied Corporate Governance, 2013, Best Corporate Governance Practice, Applied Corporate Governance, http://www.applied-corporate-governance.com/best-corporate-governance-practice.html, accessed 02.12.2015

2. Clarke T. (2009). A critique of the Anglo-American Model of Corporate Governance. Comparative Research in Law \& Political Economy research paper, 05. Toronto, Canada.

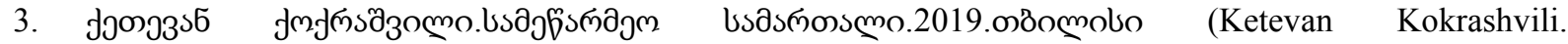
Entrepreneurial Law.2019. Tbilisi)

4. Радыгии А.Д., Эшпов Р.М. Унификация корпоративного законодательства: общемировые тенденции, законодательство ЕС и перспективы России. М., 2002. С. 34; Дементьева А.Г. Модели корпоративного управления: опыт зарубежных стран и России // Право и управление. XXI век. 2008. № 3. С. 80; Модели корпоративного управления в России: развитие и влияние на политику промышленных предприятий // Предприятия России. Корпоративное управление и рыночные сделки: сб. статей. М., 2002

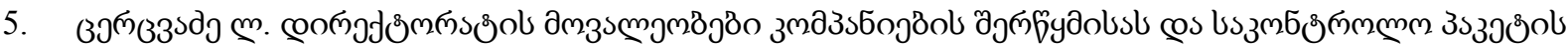

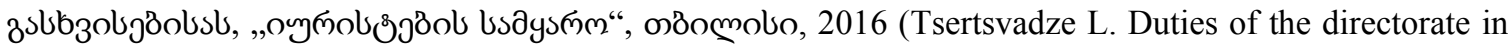
merging companies and alienating the controlling stake, "World of Lawyers", Tbilisi, 2016.)

6. Retrieved from https://corpgov.law.harvard.edu/2018/07/17/the-uk-corporate-governance-code/

7. Retrieved from https://www.icaew.com/technical/corporate-governance/principles/principles-articles/doescorporate-governance-matter

8. Retrieved from https://www.icsa.org.uk/about-us/policy/what-is-corporate-governance

9. Retrieved from https://www.papertyari.com/general-awareness/management/corporate-governance-models/

10. Retrieved from https://frenchcorporategovernance.wordpress.com/the-french-model/

11. Retrieved from https://uk.practicallaw.thomsonreuters.com/w-026-

0629? originationContext $=$ document\&transitionType $=$ DocumentItem\& contextData $=($ sc.Default $) \&$ firstPage $=$ true

12. Peter Yeoh. Corporate governance models: Is there a right one for transition economies in Central and Eastern Europe? ISSN: 0309-0558. Publication date: 22 May 2007. Retrieved from https://www.emerald.com/insight/content/doi/10.1108/03090550710816483/full/html?skipTracking=true 